\title{
Characteristics of Organic Matters in Influents and Effluents of Sewage Treatment Plants in Gyeongsanbuk-do
}

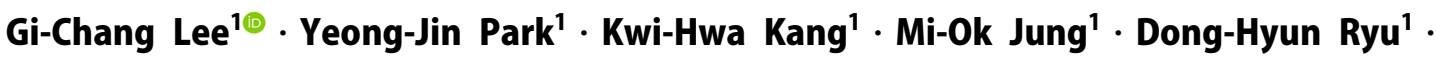 \\ Sang-Sub Jung ${ }^{1} \cdot$ Wontae Lee $^{2,+\oplus}$
}

${ }^{1}$ Water Analysis Section, Institute of Gyeongsangbukdo Health \& Environment

${ }^{2}$ Department of Environmental Engineering, Kumoh National Institute of Technology

(Received March 12, 2021; Revised May 12, 2021; Accepted May 24, 2021)

Objectives: This study aimed to provide scientific information on the characteristics of organic matters in influents and effluents of sewage treatment plants (STPs) in Gyeongbuk province, Korea, for better performance of treatment processes in the plants.

Methods: We selected six STPs with each capacity over $30,000 \mathrm{~m}^{3} /$ day in Gyeongbuk province, and analyzed water quality data in influents and effluents of the plants from 2013 to 2020. Also, the removal efficiencies of pollutants were assessed with the operational data. In 2020, characteristics and origins of dissolved organic matters (DOM) in influents and effluents were investigated using the fluorescence excitation emission matrix (FEEM) analysis.

Results and Discussion: The average $\mathrm{BOD}_{5} / \mathrm{COD}_{\mathrm{Mn}}$ ratios of influents and effluents from the STPs were 1.60 and 0.27 , respectively. High variability in $\mathrm{BOD}_{5} / \mathrm{COD}_{\mathrm{Mn}}$ ratios was observed for both influents and effluents. The $\mathrm{COD}_{\mathrm{Mn}} / \mathrm{TOC}$ ratios of the influents and effluents were the same with an average of 1.6. Although the biological treatment process was different for each STP, the organic matter removal efficiency was similar, and the TOC removal efficiency was $86.5 \sim 91.7 \%$. The representative spectra of DOM identified through FEEM analysis was peak $\mathrm{C}$ (humic-acid like substance) region, and under the same carbon concentration $(2 \mathrm{mg}-\mathrm{C} / \mathrm{L})$ the fluorescence intensity of effluents was stronger than influents possibly due to the influence of soluble microbial products (SMP). It was found that DOM of both influent and effluent originated from microorganisms, and the difference in water quality of DOM was statistically significant.

Conclusions: The characteristics and fate of organic matters in influents and effluents of the six STPs were similar regardless of plant location. The results of this study can be used as basic information to efficiently control organic matters in the STPs.

Keywords: Sewage Treatment Plants, Influent, Effluent, Dissolved Organic Matter, EEM 


\title{
연구논문
}

\section{경북지역 공공하수처리시설 유입수 및 방류수의 유기물 특성}

\author{
이기창 ${ }^{1 \oplus} \cdot$ 박영진 $^{1} \cdot$ 강귀화 $^{1} \cdot$ 정미옥 $^{1} \cdot$ 류동현 $^{1} \cdot$ 정상섭 $^{1} \cdot$ 이원태 $^{2,+\odot ~}$ \\ ${ }^{1}$ 경상북도보건환경연구원 수질조사과 \\ 금오공과대학교 환경공학과
}

목적 : 본 연구는 경북지역 내 대표적인 공공하수처리시설의 유입수 및 유출수 내 유기물 특성을 분석하고 이를 통 해 처리시설의 효율적인 운영을 도모하고자 수행하였다.

방법: 경북지역의 공공하수처리시설 중 시설규모 $30,000 \mathrm{~m}^{3} / \mathrm{day}$ 이상인 6 곳을 선정하여 2013 2020년 동안의 운영 자료를 활용하여 유입수 및 방류수의 수질특성과 공정효율을 분석하였다. 2020년 시료는 형광 excitation emission matrix (EEM) 분석기법을 활용하여 유입수 및 방류수의 용존유기물질(Dissolved Organic Matter, DOM) 특성과 생 성기원 등을 조사하였다.

결과 및 토의: 분석대상 공공하수처리시설의 유입수와 방류수의 $\mathrm{BOD}_{5} / \mathrm{COD}_{\mathrm{Mn}}$ 평균비는 각각 1.60 과 0.27 이었다. $\mathrm{BOD}_{5} / \mathrm{COD}_{\mathrm{Mn}}$ 비는 유입수 뿐만 아니라 생물학적처리가 된 방류수에서도 변동성이 크게 나타났다. 유입수와 방류 수의 $\mathrm{COD}_{\mathrm{Mn}} / \mathrm{TOC}$ 비는 평균 1.6 으로 동일하였다. 처리시설별로 생물학적공법이 상이하였지만 유기물 제거효율은 유사하게 나타났으며, TOC의 경우 제거효율은 86.5 91.7\%이었다. 형광 EEM 분석을 통해 확인된 DOM의 대표적 EEM spectra는 peak C (humic-acid like substance) 영역이었고, 동일한 탄소농도 $(2 \mathrm{mg}-\mathrm{C} / \mathrm{L})$ 조건에서 방류수가 미 생물의 대사활동으로 생성된 soluble microbial products (SMP)의 영향으로 형광강도가 더 강했다. 유입수와 방류수 의 $\mathrm{DOM}$ 은 모두 미생물로부터 기인한 것으로 나타났고, $\mathrm{DOM}$ 의 수질성상 차이는 통계적으로 유의하였다.

결론 : 조사대상 공공하수처리시설간 유입수 및 방류수에 대한 유기물질의 거동이 유사하고 다양한 유기물 성상지 표가 비교적 균일한 값을 가져 본 연구의 결과가 향후 수처리공정에서 유기물질을 효율적으로 제어하기 위한 기초 자료로 활용 가능할 것이다.

주제어 : 공공하수처리시설, 유입수, 방류수, 용존유기물질, EEM

\section{1. 서론}

하·폐수 내 용존유기물질(dissolved organic matter, DOM) 은 아미노산, 단당류 등 저분자량 유기물질에서 휴믹산, 단백 질계, 다당류 등 고분자량 유기물질에 이르기까지 높은 다양 성을 가진 비균질성 혼합물질이다. ${ }^{1)}$ 최근에는 분석기술의 발 달로 인해 의약물질, 호르몬물질 등 여러 신규유기오염물질들 이 하-폐수에서 확인되고 있다. ${ }^{2}$ 이처럼 하-폐수의 유기물 성 상은 다양하고 복잡한 특성을 가져 수처리 후에도 호수, 강, 연안해역의 공공수역에 미치는 유기물 부하와 위험성은 여전 히 존재한다. 또한, 유기물질은 염소소독부산물 생성, 막 오염, 배급수관망에서의 생물학적 안전성 등의 문제를 일으키는 원 인물질로 유기물질의 유형과 함량에 따라 수처리 공정에 많은 영향을 준다. ${ }^{3-5)}$ 유기오염물질에 대한 모니터링 방법은 일반 적으로 화학적산소요구량(chemical oxygen demand, COD), 생물화학적산소요구량(biochemical oxygen demand, BOD), 총유기탄소량(total organic carbon, TOC)과 같은 수질오염지 표가 많이 사용된다. $\mathrm{COD}$ 와 $\mathrm{BOD}$ 는 유기물 분해에 소요되는 산소요구량을 나타내는 것으로 실제 유기물 농도 지표가 아닌 간접 지수이고, $\mathrm{TOC}$ 는 비균질적인 특성을 가진 $\mathrm{DOM}$ 의 독립 적 탄소원을 전체 탄소량으로 나타낸다. 이러한 총량적인 지 표들은 유기물질 농도에 관한 정보만 제공할 뿐 복잡한 $\mathrm{DOM}$ 의 구조적 특성에 대한 정보를 제공할 수 없다. 하-폐수 내 $\mathrm{DOM}$ 은 자연유기물질(natural organic matter, NOM) 성상변 화와 정수처리공정에 영향을 미치므로 하·폐수 내 유기물질 의 이해와 관리는 반드시 필요하며, 이를 위해서는 유기물에 대한 기초적 특성파악이 무엇보다 중요하다.

일반적인 유기물질 성상분석법으로는 방향족 탄소성분을 나타내는 고유흡광도(specific UV absorbance, SUVA), 분자량 크기 분포를 측정할 수 있는 크기별 배제 크로마토그래피(size 
Table 1. Summary of sewage treatment plants monitored.

\begin{tabular}{|c|c|c|c|c|c|}
\hline STP & $\begin{array}{l}\text { Capacity } \\
\left(\mathrm{m}^{3} / \text { day }\right)\end{array}$ & $\begin{array}{c}\text { Wastewater from } \\
\text { non-residential sources (\%) }\end{array}$ & Biological process & $\begin{array}{l}\text { Post-chemical treatment } \\
\text { for TP removal }\end{array}$ & Filtration facility \\
\hline$A$ & 232,000 & 14 & BIO-SAC $\left(\mathrm{A}_{2} \mathrm{O}\right)^{[1]}$ & - & $\mathrm{MDF}^{[7]}$ filtration \\
\hline B & 110,000 & 5 & $\mathrm{AO}^{[2]}$ & - & - \\
\hline C & 80,000 & 20 & $\mathrm{TEC}^{-B N R^{[3]}}$ & $\mathrm{PAC}+\mathrm{DAF}^{[6]}$ & - \\
\hline D & 330,000 & 70 & $\mathrm{DNR}^{[4]}$ & Co-precipitation with PAC & Sand filtration \\
\hline $\mathrm{E}$ & 31,000 & 4 & $\mathrm{~A}_{2} \mathrm{O}$ & PAC+Sedimentation & - \\
\hline $\mathrm{F}$ & 40,000 & 3 & $\mathrm{NPR}^{[5]}$ & $\mathrm{PAC}+\mathrm{DAF}$ & $\mathrm{DDF}^{[8]}$ filtration \\
\hline
\end{tabular}

BIO-SAC (Anaerobic-Anoxic-Aerobic) ${ }^{[1]}$, Anaerobic-Aerobic ${ }^{[2]}$, Taeyoung External Carbon addition-Biological Nutrient Removal ${ }^{[3]}$, Daewoo Nutrient Removal $^{[4]}$, Nitrogen \& Phosphorus Removal ${ }^{[5]}$, Poly Aluminum Chloride+Dissolved Air Flotation ${ }^{[6]}$, Micro Disk Filter ${ }^{[7]}$, Disk Diatomite Filter ${ }^{[8]}$

exclusion chromatography), 소수성/친수성 유기물질 성분분 리에 사용하는 수지분리법(resin fractionation)과 ${ }^{13} \mathrm{C}-\mathrm{NMR}$ (nuclear magnetic resonance), 적외선 분광법(FT-IR), 형광분 석법과 같은 분광분석법 등이 있다. ${ }^{6}$ 이 중 형광분석법은 $\mathrm{DOM}$ 성상을 높은 분석감도로 빠르고 간단하게 분석할 수 있어 분리 및 추출 등 복잡한 시료 전처리를 요구하는 다른 분석 방법보다 물 환경 내의 DOM에 대한 다양한 정보를 현장에서 실시간으로 비교적 손쉽게 확보할 수 있다는 장점이 있다. ${ }^{6,7)}$ 형광 excitation-emission matrix (EEM) 분석은 형광분광기를 이 용하여 시료의 형광물질에 반응하는 excitation-emission 파장의 강도(intensity)를 측정한 후 형광강도 지형을 생성하면 시료 내 $\mathrm{DOM}$ 의 공간적 분획특성 정보를 알 수 있다. ${ }^{8)}$ 형광 $\mathrm{EEM}$ 분석기법은 정수공정에서 유기물 제거 및 성상 연구에 많이 적용해 왔으나 최근에는 하수 재이용에 대한 관심 증가로 하수 내 유기물 특성분석에도 널리 활용되고 있다. 먹는 물 및 재이 용수 수처리 공정에서 유기물 제거변화 모니터링, 용존유기물 질과 미량금속성분 간의 상호작용특성, anaerobic ammonium oxidation (anammox) 공정에서 방류수에 대한 유기물 특성, 생물대사산물(soluble microbial products, SMP)과 방류수에 대한 상호관계, 생물학적처리에 따른 유기물 성상변화 등 다 양한 분야에서 유기물질의 특성을 입증하는데 응용하였 다. ${ }^{8-12)}$ 이처럼 보고된 자료의 대다수가 수처리 공정에 의한 방류수의 DOM 성상 및 변형을 연구한 것으로 공공하수처리 시설의 유입수 및 방류수에 대한 유기물 성상을 비교분석한 연구자료는 부족한 실정이다. ${ }^{13-15)}$

이에 본 연구를 통해 경북지역 내 대표적인 공공하수처리시 설 6곳(시설규모 $30,000 \mathrm{~m}^{3} / \mathrm{day}$ 이상)을 선정하고 유입수 및 유출수 내 유기물 특성을 분석하여 처리시설의 효율적인 운영 을 도모할 수 있는 정보를 제공하고자 한다.

\section{2. 재료 및 방법}

\section{1. 대상시설현황}

연구를 위해 경상북도 내 인구 10 만 이상의 도시에 위치한 시설규모 $30,000 \mathrm{~m}^{3} /$ day 이상인 공공하수처리시설 6 개소(A,
$\mathrm{B}, \mathrm{C}, \mathrm{D}, \mathrm{E}, \mathrm{F})$ 를 선정하였다(Table 1). 대상시설 중 처리용량 이 가장 큰 곳은 $\mathrm{D}$ 시설 $\left(330,000 \mathrm{~m}^{3} / \mathrm{day}\right)$ 이었고, 가장 작은 곳은 $\mathrm{E}$ 시설 $\left(31,000 \mathrm{~m}^{3} / \mathrm{day}\right)$ 이었다. $\mathrm{D}$ 시설은 하수 $30 \%$, 비하 수 $70 \%$ 로 산업폐수 유입이 매우 높은 비중을 차지하였으며, $\mathrm{A}$ 와 $\mathrm{C}$ 시설은 비하수 연계처리율이 각각 $14 \%, 20 \%$ 이었다. 이외 시설들은 축산분뇨 등의 연계처리 비중이 $5 \%$ 이내로 낮 았다. 모든 대상시설은 부영양화물질 $(\mathrm{N}, \mathrm{P})$ 을 제어할 수 있는 고도처리공정을 생물학적처리로 적용하고 있었으며, $\mathrm{C}, \mathrm{E}, \mathrm{F}$ 시설은 생물학적처리시설 후단에 총인처리시설을 운영하고 있었다. D 시설은 호기조에서 침전조로 월류하는 지점에 응집 제(PAC)를 투입하여 인(P)을 슬러지와 공침하여 제거하는 방 법을 사용하고 있었다.

\section{2. 조사방법}

대상 공공하수처리시설의 유입수 및 방류수 수질에 대한 조 사기간은 2013 2020년으로, 이중 2013 2019년에 대한 자료 는 국가하수도정보시스템에서 수집하였고 2020년은 2 11월 동안 월 1 회씩 총 10 회 시료 채취 및 분석을 하였다. 시료는 유입수, 2차 처리수(총인처리시설 운영지점에 한함), 최종방류 수를 대상으로 채수하였다. 수질조사항목은 $\mathrm{pH}$, 전기전도도, $\mathrm{COD}_{\mathrm{Mn}}, \mathrm{BOD}_{5}, \mathrm{SS}, \mathrm{T}-\mathrm{N}, \mathrm{T}-\mathrm{P}, \mathrm{TOC}$ 이었고, 2020년에 채수한 시료는 $\mathrm{UV}_{254}$ absorbance $\left(\mathrm{UVA}_{254}\right)$, Specific $\mathrm{UV}_{254}$ absorbance (SUVA 254$)$, 용존유기탄소량(dissolved organic carbon, DOC), FEEM도 분석하였다. 다만, DOM에 대한 성상분석은 5 11월 사이 채취한 시료를 대상으로 총 7회 수행하였다.

\section{3. 분석방법}

$\mathrm{DOC}$ 는 TOC analyzer (TOC-L, Shimadzu)를 사용하여 분석 하였다. $\mathrm{UVA}_{254}$ 는 UV-visible spectrophotometer (Cary 300, Varian)을 이용하여 선택파장 $254 \mathrm{~nm}$ 에서 측정하였다. $\mathrm{SUVA}_{254}$ 값은 시료의 $\mathrm{UVA}_{254}$ 값을 $\mathrm{DOC}$ 농도로 나눈 다음 100 을 곱하 여 계산된다. TOC 분석은 고온연소산화법-비정화성유기탄소 측정법(non-purgeable organic carbon, NPOC)을 이용하였으며, 시료는 측정 중에 부유물질이 침전되지 않도록 연속적으로 교 반되도록 하였다. 특히 유입수는 입자가 큰 부유물질이 많으므 
Table 2. Concentrations and removal rates of water quality parameters in six STPs (data from 2013 to 2020).

\begin{tabular}{|c|c|c|c|c|c|c|c|c|}
\hline & Parameter & STP A & STP B & STP C & STP D & STP E & STP F & Average \\
\hline \multirow{3}{*}{$\mathrm{BOD}_{5}$} & Influent (mg/L) & $104.5 \pm 36.2^{[1]}$ & $118.5 \pm 18.4$ & $152.6 \pm 22.1$ & $114.5 \pm 23.7$ & $89.4 \pm 24.7$ & $124.4 \pm 31.9$ & $117.3 \pm 21.2$ \\
\hline & Effluent (mg/L) & $6.3 \pm 2.2$ & $2.2 \pm 0.7$ & $2.1 \pm 0.8$ & $2.4 \pm 0.7$ & $2.4 \pm 1.1$ & $1.0 \pm 0.9$ & $2.7 \pm 1.8$ \\
\hline & Removal (\%) & $93.6 \pm 2.5^{[2]}$ & $98.1 \pm 0.6$ & $98.6 \pm 0.6$ & $97.8 \pm 0.7$ & $97.0 \pm 1.8$ & $99.1 \pm 0.8$ & $97.4 \pm 2.0$ \\
\hline \multirow{3}{*}{$\mathrm{COD}_{\mathrm{Mn}}$} & Influent (mg/L) & $52.2 \pm 17.1$ & $82.1 \pm 9.3$ & $108.4 \pm 12.4$ & $73.3 \pm 11.3$ & $57.5 \pm 21.7$ & $81.1 \pm 19.8$ & $75.8 \pm 20.1$ \\
\hline & Effluent (mg/L) & $12.3 \pm 2.4$ & $8.3 \pm 1.5$ & $10.8 \pm 1.0$ & $9.6 \pm 1.0$ & $8.6 \pm 1.8$ & $8.6 \pm 1.3$ & $9.7 \pm 1.6$ \\
\hline & Removal (\%) & $75.1 \pm 5.3$ & $89.7 \pm 2.5$ & $89.9 \pm 1.7$ & $86.6 \pm 2.2$ & $82.7 \pm 7.6$ & $88.8 \pm 3.0$ & $85.5 \pm 5.7$ \\
\hline \multirow{3}{*}{ SS } & Influent (mg/L) & $101.6 \pm 42.1$ & $119.4 \pm 18.8$ & $148.3 \pm 17.5$ & $120.5 \pm 35.4$ & $98.5 \pm 41.9$ & $120.8 \pm 27.4$ & $118.2 \pm 17.8$ \\
\hline & Effluent (mg/L) & $4.7 \pm 1.4$ & $2.6 \pm 0.8$ & $4.1 \pm 0.9$ & $2.0 \pm 0.6$ & $2.0 \pm 1.2$ & $3.2 \pm 1.7$ & $3.1 \pm 1.1$ \\
\hline & Removal (\%) & $94.4 \pm 2.9$ & $97.8 \pm 0.6$ & $97.2 \pm 0.8$ & $98.3 \pm 0.6$ & $97.6 \pm 1.8$ & $97.2 \pm 2.0$ & $97.1 \pm 1.3$ \\
\hline \multirow{3}{*}{$\mathrm{T}-\mathrm{N}$} & Influent (mg/L) & $24.911 \pm 7.201$ & $23.779 \pm 4.102$ & $36.633 \pm 4.700$ & $31.243 \pm 3.459$ & $19.215 \pm 4.310$ & $30.600 \pm 20.202$ & $27.730 \pm 6.359$ \\
\hline & Effluent (mg/L) & $11.425 \pm 3.441$ & $5.996 \pm 1.482$ & $9.479 \pm 1.108$ & $8.906 \pm 1.425$ & $9.292 \pm 2.776$ & $9.267 \pm 3.325$ & $9.061 \pm 1.748$ \\
\hline & Removal (\%) & $51.9 \pm 14.4$ & $74.3 \pm 7.3$ & $73.7 \pm 4.3$ & $71.3 \pm 4.4$ & $49.3 \pm 18.3$ & $67.2 \pm 12.2$ & $64.6 \pm 11.2$ \\
\hline \multirow{3}{*}{$\mathrm{T}-\mathrm{P}$} & Influent (mg/L) & $2.492 \pm 0.863$ & $2.711 \pm 0.538$ & $3.698 \pm 0.485$ & $2.971 \pm 0.838$ & $2.257 \pm 0.664$ & $2.960 \pm 0.410$ & $2.848 \pm 0.499$ \\
\hline & Effluent (mg/L) & $0.327 \pm 0.173$ & $0.169 \pm 0.083$ & $0.119 \pm 0.031$ & $0.113 \pm 0.043$ & $0.077 \pm 0.034$ & $0.080 \pm 0.048$ & $0.148 \pm 0.094$ \\
\hline & Removal (\%) & $85.9 \pm 7.8$ & $93.5 \pm 3.5$ & $96.7 \pm 1.1$ & $96.1 \pm 1.4$ & $96.1 \pm 2.4$ & $97.2 \pm 2.0$ & $94.3 \pm 4.3$ \\
\hline
\end{tabular}

Mean \pm Standard Deviation ${ }^{[1]},\left(C_{\text {inf }}-C_{\text {eff }}\right) / C_{\text {inf }} \times 100(\%)^{[2]}$

로 초음파 분쇄장치를 이용하여 시료를 충분히 균질화 시킨 후 입경 $300 \mu \mathrm{m}$ 이하로 통과된 것을 분석하였다. $\mathrm{pH}$ 와 전기전도 도는 $\mathrm{pH}$ meter (CH/SevenMulti, Mettler-toledo)를 이용하여 측 정하였으며, $\mathrm{BOD}_{5}, \mathrm{COD}_{\mathrm{Mn}}, \mathrm{SS}$ 분석은 수질오염공정시험기 준에 준하여 수행하였다.

FEEM 분석은 형광분광광도계(RF-5301, Shimadzu)를 이용 하여 측정하였다. 기기분석전 시료는 $0.22 \mu \mathrm{m}$ 멤브레인 필터 로 여과하여 준비하였다. 형광 스펙트럼은 excitation-emission scan 분석을 통해 수집되는데 excitation 파장을 고정시킨 후 emission 파장을 변화시켜가며 시료의 형광스펙트럼을 측정 한다. 이러한 방식으로 excitation 파장을 설정한 범위에서 순 차적으로 적용하여 excitation-emission scan에 대한 측정데이 터를 얻는다. Excitation-emission scan 조건으로서 excitation 파장범위는 220 400 nm (5 nm 간격), emission 파장범위는 $250 \quad 600 \mathrm{~nm}(1 \mathrm{~nm}$ 간격)로 설정하였다. 광원은 Xenon lamp 를 이용하였고, excitation-emission slit width는 $10 \mathrm{~nm}$ 로 설정 하였다. 모든 시료는 DOC 농도를 $2 \mathrm{mg}-\mathrm{C} / \mathrm{L}$ 가 되도록 동일하 게 희석한 후 측정되었다. 시료의 EEM 측정데이터는 액체시 료에서 기본적으로 나타나는 형광스펙트럼을 증류수의 EEM 측정값을 이용하여 보정하였으며, 형광 $\mathrm{EEM}$ 분석을 위해 SigmaPlot 소프트웨어를 사용하였다. EEM 분석에서는 주로 5 가지의 fluorescence peak가 관측된다. ${ }^{16)}$ Peak A와 C는 humus-like 영역이며, 각각 $\lambda_{\mathrm{ex}} / \lambda_{\mathrm{em}}=237 \sim 260 / 400 \sim 500 \mathrm{~nm}$, $\lambda_{\mathrm{ex}} / \lambda_{\mathrm{em}}=300 \sim 370 / 400 \sim 500 \mathrm{~nm}$ 의 위치에서 발생한다. Peak B 는 tyrosine-like 영역으로 $\lambda_{\mathrm{ex}} / \lambda_{\mathrm{em}}=225 \sim 237 / 309 \sim 321 \mathrm{~nm}$ 의 위 치에서 발생한다. Peak $\mathrm{T}_{1}$ 과 $\mathrm{T}_{2}$ 는 tryptophan-like 영역이며,
각각 $\lambda_{\mathrm{ex}} / \lambda_{\mathrm{em}}=275 / 340 \mathrm{~nm}, \lambda_{\mathrm{ex}} / \lambda_{\mathrm{em}}=225 \sim 237 / 340 \sim 381 \mathrm{~nm}$ 의 위치에서 발생한다.

\section{3. 결과 및 고찰}

\section{1. 대상시설의 유입 및 방류 수질현황}

2013년부터 2020년까지 대상시설별 운영자료와 분석자료 를 토대로 유입수 및 방류수의 수질항목별 농도와 제거효율을 계산하였다(Table 2). 유입수의 경우 C 시설의 수질항목별 농 도가 다른 시설보다 1.2 2.1 배 높게 나타났고, 수질항목별 평 균농도에 대한 대상시설간 표준편차는 15.1 26.6\%이었다. 방 류수의 수질은 모든 시설에서 수질기준 이내로 안정적인 농도 분포를 보였다. 대상시설에 대한 $\mathrm{BOD}_{5}, \mathrm{SS}$ 및 T-P의 평균 제 거효율은 각각 $97.4 \%, 97.1 \%, 94.3 \%$ 이었고, $\mathrm{COD}_{\mathrm{Mn}}$ 및 $\mathrm{T}-\mathrm{N}$ 의 평균 제거효율은 각각 $85.5 \%, 64.6 \%$ 로 나타났다. BIO-SAC 공법을 사용하는 $\mathrm{A}$ 시설의 경우 $\mathrm{BOD}_{5}, \mathrm{COD}_{\mathrm{Mn}}, \mathrm{SS}$ 및 T-P의 처리효율은 나머지 시설의 평균값보다 각각 $5 \%, 12 \%, 3 \%$, $10 \%$ 정도 낮아, 방류수 농도는 다른 시설보다 다소 높았다. $\mathrm{B} F$ 시설의 경우 생물학적 공법이 각기 달랐으나 이에 따른 유기물질 제거효율의 차이는 크지 않았다. 하지만, 총질소 (T-N) 성분의 제거효율은 $\mathrm{A}_{2} \mathrm{O}$ 공법을 적용한 $\mathrm{A}$ 와 $\mathrm{E}$ 시설에서 다른 시설보다 약 $20 \%$ 낮은 특성을 보였다. 총인(T-P) 처리시 설을 운영하는 대상시설은 2차 처리수의 총인을 41.0 81.7\% 정도 처리하였고, 전체공정상 평균 $96.7 \%$ 의 총인 제거효율을 나타내었다. 이는 대상시설 중 항목별 제거효율이 비슷하고 총인처리시설이 없는 $\mathrm{B}$ 시설과 전체 공정효율을 비교하였을 

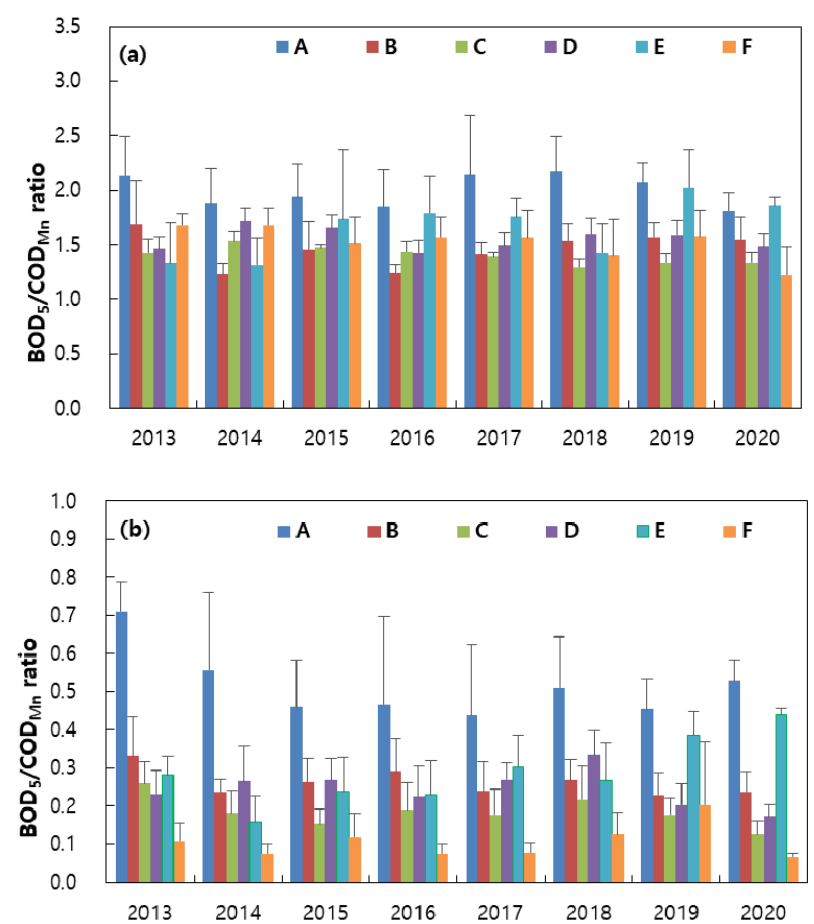

Fig. 1. Variation of $B O D_{5} / \mathrm{COD}_{\mathrm{Mn}}$ ratios of (a) influents and (b) effluents in six STPs studied.

때 약 $3 \%$ 높았다. 유입수 및 방류수의 $\mathrm{pH}$ 는 7.1 7.5 범위로 유사하였으나, 물에 녹아있는 총용존고형물(total dissolved solids, TDS)과 염분(salinity) 함량을 추정할 수 있는 수질오염 지표인 전기전도도는 $\mathrm{A}$ 시설에서 가장 높았다. $\mathrm{A}$ 시설 유입수 및 방류수의 전기전도도는 각각 $1578,2117 \mu \mathrm{S} / \mathrm{cm}$ 로 조사지 점 중 가장 높은 염 농도분포를 보였고, 다음으로는 $\mathrm{D}$ 시설에 서 각각 $1251,1353 \mu \mathrm{S} / \mathrm{cm}$ 의 값을 나타내었다. 이외 대상시설 은 $1000 \mu \mathrm{S} / \mathrm{cm}$ 이내의 농도분포를 보였다.

Fig. 1은 대상시설 유입수 및 방류수의 $\mathrm{BOD}_{5} / \mathrm{COD}_{\mathrm{Mn}}$ 농도 비율을 연도별 평균값으로 나타낸 것이다. $\mathrm{BOD}_{5} / \mathrm{COD}_{\mathrm{Mn}}$ 비 율은 생분해성 및 난분해성 유기물질 함량에 대한 비율을 나 타내는데 비율이 클수록 생분해성 유기물 함량이 많다고 할 수 있다. 대상시설간 유입수의 $\mathrm{BOD}_{5} / \mathrm{COD}_{\mathrm{Mn}}$ 비는 $1.41 ~ 2.01$ (평균 1.60) 범위로 생분해성 유기물질 비율이 높은 것이 특징 이며, A 시설에서 가장 높은 비율을 보였다. 국내 공공하수처 리시설의 유입수를 대상으로 산소호흡율(oxygen uptake rate, OUR) 측정을 통한 $\mathrm{BDCOD}$ 비율을 조사한 결과 $70 \%$ 이상이 생분해성 유기물질인 것으로 보고된 바 있으며 ${ }^{17)}$, 국내 하수 도통계 자료에 의하면 국내 유입수의 $\mathrm{BOD}_{5}$ 는 항상 $\mathrm{COD}_{\mathrm{Mn}}$ 보 다 높게 나타나 있다. 유입수에 대해 8 년간 $\mathrm{BOD}_{5} / \mathrm{COD}_{\mathrm{Mn}}$ 비 의 변동비율(표준편차/평균 $\times 100)$ 을 분석한 결과, 대상시설 중 $\mathrm{A}$ 와 $\mathrm{E}$ 시설에서 각각 $34.7 \%, 27.6 \%$ 의 높은 변동비율을 보였 으며, 방류수에 대한 변동비율도 각각 $33.4 \%, 47.0 \%$ 로 대상시 설 중 높게 나타났다. 반면에 비교적 일정한 $\mathrm{BOD}_{5} / \mathrm{COD}_{\mathrm{Mn}}$ 비율 을 가진 유입수를 처리하는 대상시설은 방류수의 $\mathrm{BOD}_{5} / \mathrm{COD}_{\mathrm{Mn}}$
비율도 안정적인 것으로 나타났다. 이러한 결과는 방류수 수 질을 통해 생분해성 및 난분해성 유기물질의 유입부하에 대한 추정을 가능하게 한다. 8 년 동안 대상시설간 방류수의 평균 $\mathrm{BOD}_{5} / \mathrm{COD}_{\mathrm{Mn}}$ 비율은 0.11 0.51(평균 0.27) 범위를 보였으며, $\mathrm{A}$ 시설을 제외한 모든 시설에서 0.3 미만으로 유지되어 생물 학적 처리가 안정적으로 되고 있음을 알 수 있다.

\section{2. 유기물질 산화비율 및 특성분석}

2020 년 조사기간 동안 6 개 대상시설 방류수의 $\mathrm{COD}_{\mathrm{Mn}} / \mathrm{TOC}$ 비는 1.5 1.7(평균 1.6) 범위로 국내 공공하수처리시설에 대해 보고된 자료 $\left(\mathrm{COD}_{\mathrm{Mn}} / \mathrm{TOC}=1.7\right)$ 와 유사한 것으로 나타났으며 ${ }^{18)}$, 방류수의 $\mathrm{TOC}$ 수질기준에 적용한 $\mathrm{COD}_{\mathrm{Mn}} / \mathrm{TOC}$ 비율 $(\mathrm{I}, \mathrm{II}$ 지역 $=1.3 ; \mathrm{III}, \mathrm{IV}$ 지역=1.6)과도 비슷한 수준을 보였다. 유입수 에 대한 $\mathrm{COD}_{\mathrm{Mn}} / \mathrm{TOC}$ 비율 또한 1.4 1.8(평균 1.6) 범위로 방 류수와 비슷한 수준을 보였는데, 이는 유입수의 $\mathrm{COD}_{\mathrm{Mn}}$ 와 $\mathrm{TOC}$ 농도에 포함된 생분해성 유기물질의 생물학적 처리비율 이 유사하여 나타난 것으로 판단된다.

대상시설 유입수 및 방류수의 TOC 농도는 각각 32.0 77.3 $\mathrm{mg} / \mathrm{L}, 4.6 \sim 10.4 \mathrm{mg} / \mathrm{L}$ 로 생물학적처리에 의해 $86.5 ~ 91.7 \%$ 정 도 처리되었으며, DOC 농도는 각각 $12.6 ~ 37.3 \mathrm{mg} / \mathrm{L}, 4.2 \sim 9.2$ $\mathrm{mg} / \mathrm{L}$ 범위로 $62.3 \sim 75.3 \%$ 의 처리효율을 보였다. 6 개 대상시설 유입수 및 방류수의 DOC/TOC 비는 각각 24.4 48.3\%(평균 $34.8 \%$ ), 88.5 96.6\%(평균 91.1\%)로 나타났다. 국내 공공하수 처리시설 4 개소를 대상으로 조사한 다른 연구 ${ }^{18}$ 에서는 유입 수와 방류수의 DOC/TOC 평균 비율이 각각 $67 \%, 76 \%$ 로 본 연구와 서로 다른 값을 보였다. 하수의 특성과 처리공정의 특 성, 그리고 분석방법 등에 의한 차이가 있을 수 있으나, 특히 유입수의 DOC/TOC 비가 본 연구보다 약 2 배 더 높은 것으로 보아 여과필터의 공극크기 차이에 의한 영향도 고려할 수 있 다. 본 연구에서는 $0.22 \mu \mathrm{m}$ 의 여과필터를 사용하였고 이전 다른 연구 ${ }^{18)}$ 에서는 $1.2 \mu \mathrm{m}$ 의 여과필터를 사용하였다.

UV 파장 254 280 nm 범위에서 유기물질에 대한 UV 흡광 도는 방향족화합물의 불포화이중결합과 $\pi-\pi$ 전자상호작용의 존재를 반영하는 인자를 나타내며, 특히 $254 \mathrm{~nm}$ 파장은 유기 물질의 방향족탄소와 강한 상관성을 가지므로 난분해성 유기 물질의 간접지표로 널리 이용되고 있다. ${ }^{19)} \mathrm{SUVA}_{254}$ 는 유기물 질의 방향족 특성과 관련이 깊으며, 일반적으로 $\mathrm{SUVA}_{254}$ 값 이 $<2.0$ 이면 친수성 및 저분자량유기물질이 많고 $\mathrm{SUVA}_{254}$ 값 이 $>4.0$ 이면 소수성 및 고분자량 유기물질을 주로 포함하고 있다. ${ }^{20)}$ 조사기간 동안 대상시설간 유입수 및 방류수에 대한 $\mathrm{UVA}_{254}$ 값은 각각 $0.137 \sim 0.331 \mathrm{~cm}^{-1}, 0.092 \sim 0.185 \mathrm{~cm}^{-1}$ 범위로 $\mathrm{DOC}$ 농도분포와 상관성 있게 나타났으며, 생물학적처리에 의한 $\mathrm{UVA}_{254}$ 제거효율은 $32.8 ~ 63.4 \%$ 정도 나타났다. $\mathrm{SUVA}_{254}$ 의 값은 각각 $0.98 \sim 1.47 \mathrm{~L} / \mathrm{mg} \cdot \mathrm{m}, 1.77 \sim 2.05 \mathrm{~L} / \mathrm{mg} \cdot \mathrm{m}$ 의 범위 를 보였으며, 방류수가 유입수보다 약 2배 높은 평균값을 나 타내었다 $(\mathrm{p}<0.01, \mathrm{n}=34)$. 유입수에 포함된 많은 친수성 및 저 

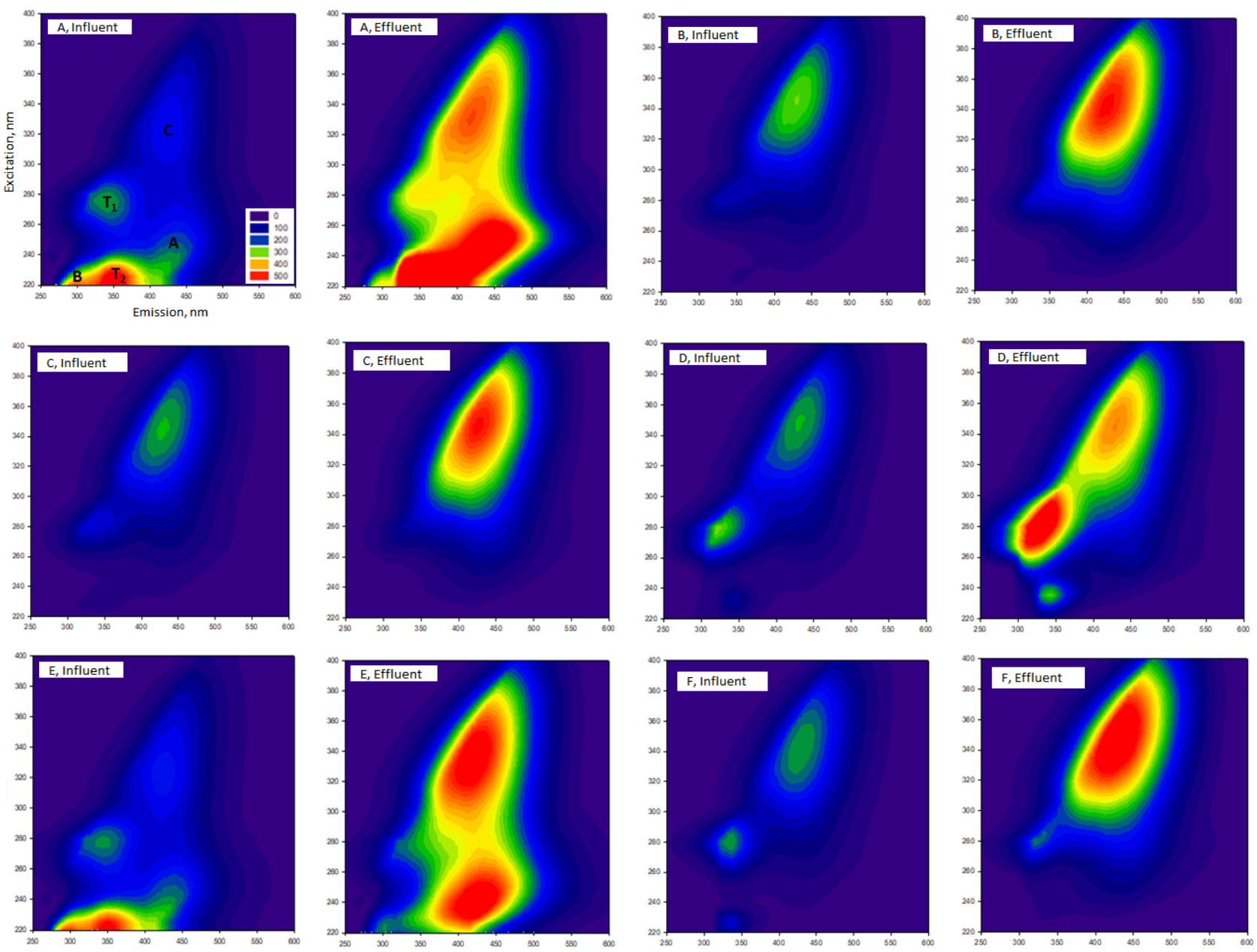

Fig. 2. FEEM spectra of influents and effluents of six STPs (sampled in November, 2020).

분자량 생분해성 유기물질이 생물학적 처리를 통해 제거되면 서 방류수는 상대적으로 난분해성 유기물질의 비중이 커져 $\mathrm{SUVA}_{254}$ 값이 증가한 것으로 판단된다.

\subsection{DOM의 EEM 분포특성}

본 연구에서 대상시료의 형광 $\mathrm{EEM}$ 을 분석한 결과, 각 $\mathrm{EEM}$ peak의 최대 형광강도(fluorescence intensity, $\mathrm{F}_{\max }$ )는 peak A: $\lambda_{\text {ex }} / \lambda_{\text {em }}=235 \sim 260 / 426 \sim 450 \mathrm{~nm}$, peak C: 325 350/417 433 nm, peak B: 225 235/309 321 nm, peak $\mathrm{T}_{1}: 275 / 340 \mathrm{~nm}$, Peak $\mathrm{T}_{2}$ : 225 235/340 381 nm의 파장 범위에서 나타났다. Fig. 2는 2020년 11월에 채취한 6 개 대상시설의 유입수 및 방류수에 대한 EEM fluorescence spectra를 나타낸 것이며, 5 10월 동 안 주요 EEM peak 형태는 B, C 시설에서 나타난 모양을 보였 다. 대상시설에서 나타난 대표적 spectra는 peak $\mathrm{C}$ 영역으로 $\lambda_{\mathrm{ex}} / \lambda_{\mathrm{em}}=200 \sim 400 \mathrm{~nm} / 300 \sim 525 \mathrm{~nm}$ 범위에서 매우 광범위한 spectra를 띠었다. 그 다음은 peak $\mathrm{T}_{1}$ 으로 대상시설간 $\mathrm{F}_{\max }$ 값 과 spectra 영역의 면적차이는 있었으나 peak C와 함께 가장 많이 출현한 유기물질 영역으로 나타났다. 특히 조사기간 동안 $\mathrm{D}$ 시설은 다른 시설보다 peak $\mathrm{T}_{1}$ 의 spectra 영역이 뚜렷하고
높은 $\mathrm{F}_{\max }$ 값을 나타내었다. 11 월에 채취한 유입수 및 방류수에 대한 EEM fluorescence spectra 중 공교롭게도 $\mathrm{BOD}_{5} / \mathrm{COD}_{\mathrm{Mn}}$ 비의 변동비율이 높았던 $\mathrm{A}$ 와 $\mathrm{E}$ 시설에서 조사된 $\mathrm{EEM}$ peak의 형태는 5 10월 동안 두 시설의 주요 peak spectra와 다르게 나타났다. 형광강도 측정시 모든 시료의 유기물 총량을 DOC 기준 $2 \mathrm{mg}-\mathrm{C} / \mathrm{L}$ 로 희석하여 측정하였으므로 결과해석에 있어 서 절대치가 아닌 상대적인 수치로 비교해야 한다. $\mathrm{E}$ 시설의 유입수는 peak B $\left(\mathrm{F}_{\max }=392.97\right)$ 와 peak $\mathrm{T}_{2}\left(\mathrm{~F}_{\max }=514.78\right)$ 영역 이 강한 spectra를 보였고, peak $\mathrm{A}, \mathrm{T}_{1}, \mathrm{C}$ 의 $\mathrm{F}_{\max }$ 는 각각 $249.00,225.27,173.79$ 의 값을 나타내었다. 방류수에 나타난 각 peak의 $\mathrm{F}_{\max }$ 값은 peak $\mathrm{A}=592.46, \mathrm{C}=589.22, \mathrm{~T}_{2}=435.11$, $\mathrm{B}=253.46, \mathrm{~T}_{1}=210.17$ 순으로 나타났다. Humus-like 영역인 peak $\mathrm{C}$ 와 $\mathrm{A}$ 의 spectra는 유입수보다 더 높은 강도를 보였고 protein-like 영역인 peak $\mathrm{B}, \mathrm{T}_{1}, \mathrm{~T}_{2}$ 의 $\mathrm{F}_{\max }$ 값은 다소 감소하였 지만 유입수와 큰 차이는 없었다. A 시설에서 유입수의 peak spectra는 $\mathrm{E}$ 와 거의 흡사하였으며, 각 peak의 $\mathrm{F}_{\max }$ 값은 peak $\mathrm{T}_{2}=578.13, \mathrm{~B}=407.51, \mathrm{~A}=244.50, \mathrm{~T}_{1}=240.02, \mathrm{C}=159.25$ 순으 로 나타났다. 방류수에 대한 각 peak의 $\mathrm{F}_{\max }$ 값은 $\mathrm{T}_{2}=991.13$, $\mathrm{A}=680.13, \mathrm{~B}=536.13, \mathrm{C}=464.95, \mathrm{~T}_{1}=339.90$ 순으로 humus-like 


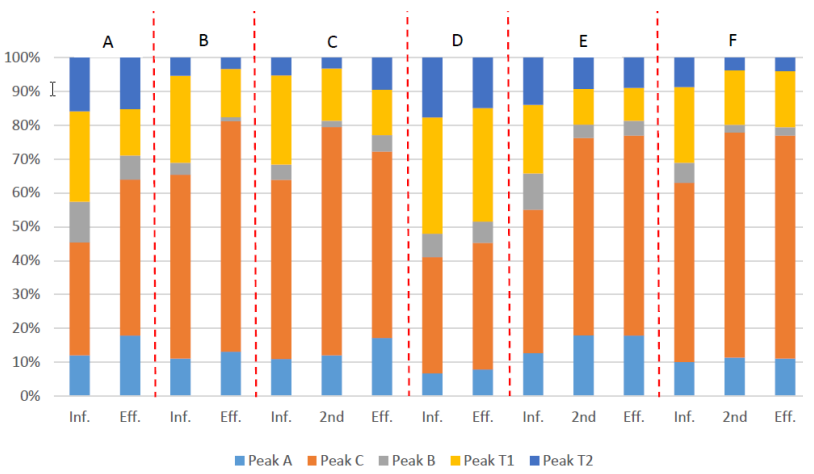

Fig. 3. Distribution of peak intensities of influents (Inf.), secondary treated wastewater (2nd), and effluents (Eff.) in six STPs.

과 protein-like 영역의 spectra가 모두 유입수보다 높았다. 두 시설에서 유입수에 대한 protein-like 영역의 fluorescence spectra는 방류수에서 비슷하거나 강하게 나타났다. 모든 대상 시설의 유입수 및 방류수에 대한 동일한 DOM 농도 $(2 \mathrm{mg}-\mathrm{C} / \mathrm{L})$ 조건에서 유입수에 나타난 EEM fluorescence spectra는 더 강한 형광강도(fluorescence intensity)와 함께 방류수에 그대로 출현 한 것이 특징이며, 방류수의 DOM은 humus-like과 protein-like 영 역을 나타내는 SMP의 영향에 의해 나타난 것으로 사료된다. ${ }^{21-23)}$

Fig. 3은 각 EEM peak의 $\mathrm{F}_{\max }$ 를 전체 구성 중 차지하는 분포 비율로 나타낸 것이다. 2 차처리수와 방류수에 대한 EEM peak 분포비율은 대체로 비슷하게 나타나 총인처리시설이 DOM 의 fluorescence spectra 변화에 미친 영향은 거의 없는 것으로 확인되었다. 생물학적처리에 의한 EEM fluorescence spectra 분포비율 변화는 주로 peak $\mathrm{C}$ 와 $\mathrm{T}_{1}$ 에서 나타났다. 유입수 및 방류수에 대해 peak C의 평균 분포비율은 각각 $45 \%$ (33 54\%), $55 \%$ (37 68\%)이었고, peak $\mathrm{T}_{1}$ 에 대해서는 각각 $26 \%(20 ~ 34 \%)$, $17 \%(10 \sim 34 \%)$ 로 나타나 생물학적처리에 의해 약 $10 \%$ 의 증 감을 보였다.

\subsection{DOM의 생성기원 특성}

FEEM 분석을 통한 DOM의 발생기원 분석은 fluorescence index (FI), biological index (BIX), Humification index (HIX) 의 지표를 통해 확인하였으며, 유입수와 방류수에 대한 각 지 수의 값을 Table 3에 나타내었다. FI 지수는 파장위치 $\lambda_{\mathrm{em}} / \lambda_{\mathrm{ex}}$ $=500 / 370 \mathrm{~nm}$ 에 대한 $\lambda_{\mathrm{em}} / \lambda_{\mathrm{ex}}=450 / 370 \mathrm{~nm}$ 의 fluorescence intensity 비율을 나타낸 것이다. ${ }^{24)} \mathrm{DOM}$ 의 생성기원은 FI 값 의 범위에 따라 달라진다. 낮은 FI 값(<1.4)은 강한 토양 기원 으로, 높은 FI 값(>1.9)은 미생물에 의한 기원으로, 그리고 1.4 $<\mathrm{FI}<1.9$ 이면 토양과 미생물의 복합기원으로 구분하고 있 다. ${ }^{24)}$ 본 연구에서 조사한 FI 값은 평균 $2.2 \pm 0.08$ 으로 6 개 대상 시설 유입수 및 방류수 모두에서 유사한 값을 보여 $\mathrm{DOM}$ 의 기원은 미생물로부터 기인한 것으로 나타났다.

$\mathrm{BIX}$ 지수는 파장위치 $\lambda_{\mathrm{em}} / \lambda_{\mathrm{ex}}=430 / 310 \mathrm{~nm}$ 에 대한 $\lambda_{\mathrm{em}} / \lambda_{\mathrm{ex}}$
Table 3. EEM index of influents and effluents in six STPS.

\begin{tabular}{|c|c|c|c|}
\hline & $\mathrm{FI}$ & $B \mid X^{[1]}$ & $H X^{[2]}$ \\
\hline Influent & $2.2 \pm 0.05$ & $0.8 \pm 0.10$ & $1.5 \pm 0.97$ \\
\hline Effluent & $2.2 \pm 0.10$ & $1.0 \pm 0.07$ & $2.9 \pm 1.49$ \\
\hline
\end{tabular}

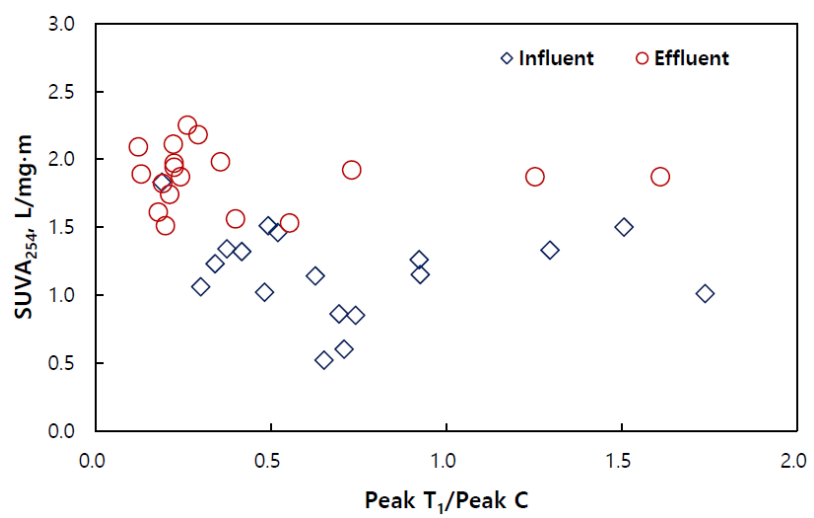

Fig. 4. Distribution of SUVA 254 and peak $T_{1} /$ peak $C$ for influents and effluents of six STPs.

$=380 / 310$ 의 fluorescence intensity 비율을 산정하여 독립영 양 생산성의 지표를 나타낸 값이다. ${ }^{25)} \mathrm{BIX}$ 지수 값이 1 이상 으로 높으면 미생물로부터 최근 자생된 DOM을 의미하며 (autochthonous), 낮은 값 $(<0.6)$ 은 오래전 생성된 외래성의 DOM에 해당된다(allochthonous). ${ }^{25)}$ 본 연구에서 유입수와 방 류수에 대한 BIX 지수를 조사한 결과 분포도가 확연히 구분 되는 것을 알 수 있다. 방류수의 BIX 평균값은 1.0 으로 유입수 보다 0.2 정도 더 높게 나타났는데 $(\mathrm{p}<0.01, \mathrm{n}=34)$, 이는 미생 물의 대사활동에 의해 생성된 독립영양 유기물질인 $\mathrm{SMP}$ 의 영향으로 보여진다.

Humification index (HIX)는 파장위치 $\lambda_{\mathrm{em}} / \lambda_{\mathrm{ex}}=(300 \sim 345) /$ $254 \mathrm{~nm}$ 에 대한 $\lambda_{\mathrm{em}} / \lambda_{\mathrm{ex}}=(435 \sim 480) / 254 \mathrm{~nm}$ 의 형광강도 면적 비율을 나타낸 값으로, 자연계에서 유기물질의 생체이용률을 판단하는 지표로 휴믹화 정도를 조사하기 위해 활용된다. ${ }^{26}$ $\mathrm{HIX}$ 지수 값이 높을수록 휴믹화 정도가 더 큰 것을 의미하며, 구조적으로 복잡하고 화학적으로 비교적 안정적인 DOM을 나 타낸다. ${ }^{27,28)}$ 본 연구 대상시설의 유입수 및 방류수의 HIX 지수 값은 peak A (fulvic acid-like) 영역에 해당하는 fluorescence spectra의 강도가 약해 비교적 높은 수준으로 산정되지는 않았 다. 하지만 방류수에 대한 HIX 지수의 평균값은 2.9 로 유입수 보다 약 2 배 높은 통계적 유의한 값을 보였으며 $(\mathrm{p}<0.01, \mathrm{n}=34)$, 이는 방류수가 유입수보다 화학적으로 더 안정하고 휴믹화된 $\mathrm{DOM}$ 성상을 가진 것을 의미한다.

Fig.4는 유입수와 방류수의 DOM에 대한 단백질계 및 휴믹 산계의 형광비율(peak $\mathrm{T}_{1} /$ peak C)과 $\mathrm{SUVA}_{254}$ 값의 관계분포 를 나타낸 것이다. 유입수와 방류수에 대한 평균 peak $\mathrm{T}_{1} /$ peak $\mathrm{C}$ 비는 각각 $0.7 \pm 0.42,0.4 \pm 0.41$ 로 생물학적처리로 인해 유입 
수의 단백질계 형광비율이 방류수에서 감소되는 것을 알 수 있으며, 통계적으로 유의한 분포를 보였다 $(\mathrm{p}<0.05, \mathrm{n}=34)$. $\mathrm{SUVA}_{254}$ 값은 peak $\mathrm{T}_{1} /$ peak C 비율이 낮은 방류수에서 높았 는데, 유입수 내 단백질계 등 저분자량 유기물이 생물학적처 리에 의해 제거되고 방류수에는 생성된 SMP, 휴믹산계 등 방 향족 탄소 성분이 증가하였기 때문으로 판단된다.

\section{4. 결 론}

본 연구는 경상북도에 위치한 대표적 공공하수처리시설 6 개소를 대상으로 유입수 및 방류수의 유기물질 특성을 조사하 였으며 다음과 같은 결론을 도출하였다.

1) 2013 2020년 동안 대상시설별 유입수의 $\mathrm{BOD}_{5}, \mathrm{COD}_{\mathrm{Mn}}$, $\mathrm{SS}, \mathrm{T}-\mathrm{N}, \mathrm{T}-\mathrm{P}$ 농도 편차비율은 각각 $18.1 \%, 26.6 \%, 15.1 \%$, $22.6 \%, 17.5 \%$ 이었고, 방류수의 수질은 모든 대상시설에서 수 질기준 이내로 안정적이었다. 생물학적공법에 따른 유기물 제 거효율은 대체로 비슷하였다.

2) 유입수 및 방류수의 $\mathrm{COD}_{\mathrm{Mn}} / \mathrm{TOC}$ 비율은 평균 1.6으로 대상시설에 관계없이 비슷하였으며, TOC 농도범위는 각각 $32.0 \sim 77.3 \mathrm{mg} / \mathrm{L}, \quad 4.6 \sim 10.4 \mathrm{mg} / \mathrm{L}$ 로 생물학적공정에 의해 $86.5 \sim 91.7 \%$ 정도 처리되었다.

3) 유입수 및 방류수를 대표하는 EEM fluorescence spectra 는 peak C (humic acid-like) 영역으로 방류수의 상대적 spectra intensity는 공정미생물의 SMP 영향으로 인해 유입수보다 강 하고 광범위하게 나타났다.

4) 유입수 및 방류수의 FI 값은 평균 2.2로 동일하였으며, $\mathrm{DOM}$ 의 생성기원은 미생물로부터 기인한 것으로 나타났다.

5) 유입수에 대한 BIX 지수, $\mathrm{HIX}$ 지수, $\mathrm{SUVA}_{254}$ 의 평균값 은 각각 $1.0,1.5,1.2$ 이고 방류수는 각각 $0.8,2.9,1.9$ 로서 유입 수 및 방류수의 DOM에 대한 성상차이는 통계적으로 유의하 였다.

6) 조사대상 6 개 공공하수처리시설의 유입수 및 방류수에 포함된 유기물질의 거동이 유사하고 대상시설에 관계없이 유 기물 성상지표가 비교적 균일한 값을 나타내므로 향후 하수처 리시설에서 유기물질의 특성을 파악하고 효율적으로 제어하 기 위한 기초자료로 활용 가능할 것이다.

\section{Acknowledgements}

본 연구는 경상북도의 지원과 환경부의 재원으로 국립환경 과학원(NIER-2020-01-03-001)의 지원, 그리고 정부(과학기술 정보통신부)의 재원으로 국가과학기술연구회 창의형 융합연 구사업(No. CAP-18-07-KICT)의 지원을 받아 수행하였습니 다. 또한 수질분석에 도움을 주신 보건환경연구원 수질조사과 권수경, 정지수 연구원과 금오공과대학교 환경공학과 김성범, 한주은 연구원에게 진심으로 감사의 인사를 전합니다.

\section{References}

1. F. J. Rodríguez-Vidal, M. García-Valverde, B. Ortega-Azabache, Á. González-Martínez, A. Bellido-Fernández, Characterization of urban and industrial wastewaters using excitation-emission matrix(EEM) fluorescence: searching for specific fingerprints, J. Environ. Manage., 263, 110396(2020).

2. M. Sgroi, P. Roccaro, G. V. Korshin, V. Greco, S. Sciuto, T. Anumol, S. A. Snyder, F. G. A. Vagliasindi, Use of fluorescence EEM to monitor the removal of emerging contaminants in full scale wastewater treatment plants, J. Hazard. Mater., 323, 367-376(2017).

3. F. Zhang, Y. Wang, Y. Chu, B. Gao, Q. Yue, Z. Yang, Q. $\mathrm{Li}$, Reduction of organic matter and trihalomethane formation potential in reclaimed water from treated municipal wastewater by coagulation and adsorption, Chem. Eng. J., 223, 696-703(2013).

4. I. Michael-Kordatou, C. Michael, X. Duan, X. He, Dissolved effluent organic matter: characteristics and potential implications in wastewater treatment and reuse applications, Water Res., 77, 213-248(2015).

5. H. Son, H. S. Yoom, C. D. Seo, S. G. Kim, Y. S. Kim, Evaluation of dissolved organic matter removal characteristics in GAC adsorption process in drinking water treatment process using LC-OCD-OND, J. Korean. Soc. Environ. Eng., 40(5), 239-250(2020).

6. J. Hur, M. K. Kim, S. W. Park, Analyses of synchronous fluorescence spectra of dissolved organic matter for tracing upstream pollution sources in rivers, J. Korean. Soc. Environ. Eng., 29(3), 317-324(2007).

7. W. Li, C. Liang, L. Dong, X. Zhao, H. Wu, Accumulation and characteristics of fluorescent dissolved organic matter in loess soil-based subsurface wastewater infiltration system with aeration and biochar addition, Environ. Pollut., 269, 116100(2021).

8. H. Yu, F. Qu, L. Sun, H. Liang, Z. Han, H. Chang, S. Shao, G. Li, Relationship between soluble microbial products (SMP) and effluent organic matter (EfOM): characterized by fluorescence excitation emission matrix coupled with parallel factor analysis, Chemosphere, 121, 101-109(2015).

9. M. Ruscalleda, B. Seredynska-Sobecka, B. J. Ni, E. Arvin, M. D. Balaguer, J. Colprim, B. F. Smets, Spectrometric characterization of the effluent dissolved organic matter from an anammox reactor shows correlation between the EEM signature and anammox growth, Chemosphere, 117, 271-277(2014).

10. E. Cohen, G. J. Levy, M. Borisover, Fluorescent components of organic matter in wastewater: efficacy and selectivity of the water treatment, Water Res., 55, 323-334(2014).

11. H. Yu, Y. Song, X. Tu, E. Du, R. Liu, J. Peng, Assessing removal efficiency of dissolved organic matter in wastewater treatment using fluorescence excitation emission matrices with parallel factor analysis and second derivative synchronous fluorescence, Bioresour. Technol., 144, 595-601 (2013). 
12. H. Yu, F. Qu, H. Chang, S. Shao, X. Zou, G. Li, H. Liang, Understanding ultrafiltration membrane fouling by soluble microbial product and effluent organic matter using fluorescence excitationeemission matrix coupled with parallel factor analysis, Int. Biodeterior. Biodegradation, 102, 56-63(2015).

13. N. H. Tran, H. H. Ngo, T. Urase, K. Y. Gin, A critical review on characterization strategies of organic matter for wastewater and water treatment processes, Bioresour. Technol., 193, 523-533(2015)

14. P. Jin, X. Jin, V. A. Bjerkelund, S. W. Østerhus, X. C. Wang, L. Yang, A study on the reactivity characteristics of dissolved effluent organic matter (EfOM) from municipal wastewater treatment plant during ozonation, Water Res., 88 , 643-652(2016).

15. J. Hur, T. H. Lee, B. M. Lee, Estimating the removal efficiency of refractory dissolved organic matter in wastewater treatment plants using a fluorescence technique, Environ. Technol., 32, 1843-1850(2011).

16. P. K. Henderson, A. Baker, K. R. Murphy, A. Hambly, R. M. Stuetz, S. J. Khan, Fluorescence as a potential monitoring tool for recycled water systems: a review, Water Res., 43, 863-881(2009).

17. B. J. Lee, Assessment of biodegradable and refractory COD fractions using oxygen utilization rate and ultimate biochemical oxygen demand tests, KSWST Jour. Wat. Treat., 25(4), 53-61(2017).

18. Y. B. Cho, Y. K. Oh, D. C. Shin, C. H. Park, Distribution of total organic carbon and correlations between organic matters of sewage treatment plants, J. Korean Soc. Environ. Anal., 17, 207-214(2014).

19. N. Ates, M. Kitis, U. Yetis, Formation of chlorination by-products in waters with low SUVA-correlations with SUVA and differential UV spectroscopy, Water Res., 41, 4139-4148(2007).

20. S. S. Kaplan Bekaroglu, N. O. Yigit, T. Karanfil, M. Kitis, The adsorptive removal of disinfection by-product precursors in a high-SUVA water using iron oxide-coated pumice and volcanic slag particles, J. Hazard. Mater., 183, 389-394(2010).

21. W. Song, C. Zhao, S. Mu, X. Pan, D. Zhang, F. A. Al-Misned, M. G. Mortuza, Effects of irradiation and $\mathrm{pH}$ on fluorescence properties and flocculation of extracellular polymeric substances from the cyanobacterium Chroococcus minutus, Colloids Surf. B., 128, 115-118(2015).

22. M. Ruscalleda, B. Seredynska-Sobecka, B. J. Ni, E. Arvin, D. M. Balaguer, J. Colprim, F. Smets, Spectrometric characterization of the effluent dissolved organic matter from an anammox reactor shows correlation between the EEM signature and anammox growth, Chemosphere, 117, 271-277(2014).

23. L. Dominguez, M. Rodriguez, D. Prats, Effect of different extraction methods on bound EPS from MBR sludges. Part I: Influence of extraction methods over three-dimensional EEM fluorescence spectroscopy fingerprint, Desalination,
261, 19-26(2010).

24. D. M. McKnight, E. W. Boyer, P. K. Westerhoff, P. T. Doran, T. Kulbe, D. T. Andersen, Spectrofluorometric characterization of dissolved organic matter for indication of precursor organic material and aromaticity, Limnol. Oceanogr., 46, 38-48(2001).

25. A. Huguet, L. Vacher, S. Relexans, S. Saubusse, J. M. Froidefond, E. Parlanti, Properties of fluorescent dissolved organic matter in the Gironde Estuary, Org. Geochem., 40, 706-719(2009)

26. S. Singh, E. J. D'Sa, E. M. Swenson, Chromophoric dissolved organic matter (CDOM) variability in Barataria Basin using excitation-emission matrix (EEM) fluorescence and parallel factor analysis (PARAFAC), Sci. Total Environ., 408, 3211-3222(2010).

27. W. Dong, J. Wan, T. K. Tokunaga, B. Gilbert, K. H. Williams, Transport and humification of dissolved organic matter within a semi-arid floodplain, J. Environ. Sci., 57, 24-32(2017).

28. T. Ohno, Fluorescence inner-filtering correction for determining the humification index of dissolved organic matter, Environ. Sci. Technol., 36, 742-746(2002).

\section{Declaration of Competing Interest}

The authors declare that they have no known competing financial interests or personal relationships that could have appeared to influence the work reported in this paper.

\section{Authors and Contribution Statement}

\section{Gi-Chang Lee}

Water Analysis Section, Institute of Gyeongsangbukdo Health \& Environment, Researcher, ORCID(D) 0000-0001-8387-0981: Conceptualization, Methodology, Validation, Writing - Original Draft.

\section{Yeong-Jin Park}

Water Analysis Section, Institute of Gyeongsangbukdo Health \& Environment, Researcher: Data analysis.

\section{Kwi-Hwa Kang}

Water Analysis Section, Institute of Gyeongsangbukdo Health \& Environment, Researcher: Data analysis.

\section{Mi-Ok Jung}

Water Analysis Section, Institute of Gyeongsangbukdo Health \& Environment, Researcher: Data analysis. 


\section{Dong- Hyun Ryu}

Water Analysis Section, Institute of Gyeongsangbukdo Health \& Environment, Researcher: Data analysis.

\section{Sang-Sub Jung}

Water Analysis Section, Institute of Gyeongsangbukdo Health \& Environment, Researcher: Data analysis.

\section{Wontae Lee}

Department of Environmental Engineering, Kumoh National Institute of Technology, Professor, ORCID (C) 0000-0001-9660-4455:

Conceptualization, Validation, Writing - review and editing. 